\title{
Cohesin Subunit SA-1
}

National Cancer Institute

\section{Source}

National Cancer Institute. Cohesin Subunit SA-1. NCI Thesaurus. Code C131228.

Cohesin subunit SA-1 (1258 aa, $144 \mathrm{kDa}$ ) is encoded by the human STAG1 gene. This protein plays a role in the cohesion of sister chromatids. 